\title{
Tímabundin tannholdsfærsla fyrir máttöku
}

\author{
Slembin, klínísk samanburðarrannsókn á \\ notkun práða, álklóríð-kvoðu og sambland \\ af aðferðunum tveimur
}

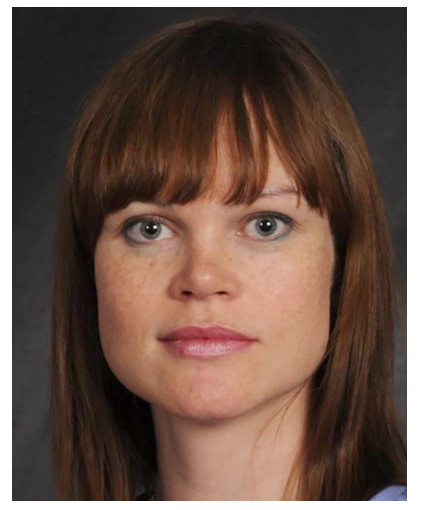

\author{
ERNA RÚN EINARSDÓTTIR, CAND.ODONT. MS, LEKTOR Í TANN- OG MUNNGERVALAEKNINGUM, TANNLAEKNADEILD \\ HÁSKÓLA ÍSLANDS \\ NIKLAUS P. LANG, DR MED DENT, MS, PHD, PROFESSOR EMERITUS, UNIVERSITY OF BERN OG UNIVERSITY OF ZURICH \\ THOR ASPELUND, MS, PHD, PROFESSOR, HEILBRIGĐISVÍSINDASVIĐ, LAEKNADEILD HÁSKÓLA ÍSLANDS \\ BJARNI ELVAR PJETURSSON, DOKTOR ODONT, DR. MED. DENT, MAS PERIO, PRÓFESSOR Í MUNN- OG \\ TANNGERVALAEKNINGUM, TANNLAEKNADEILD HÁSKÓLA ÍSLANDS
}

NETFANG: ERE@HI.IS TANNLAEKNABLAĐIĐ 2019; 37: 52-60

doi: 10.33112/tann.37.1.6

\section{ÁGRIP}

Tilefni rannsóknar. Tannholdsrýrnun vegna tannholdsfærslu fyrir máttöku í tanngervasmíði gæti orðið útlitslegt vandamál fyrir sjúklinga. Takmarkað er vitað um viðbrögð mjúkvefs við algengum aðferðum við tannholdsfærslu.

Tilgangur. Tilgangur pessarar slembnu klínísku rannsóknar var að meta breytingar í hæð tannholdsbrúnar eftir 3 mismunandi aðferðir við tannholdsfærslu fyrir máttöku við tanngervasmíði. Auk pess voru viðbrögð sjúklinga könnuð og tannsmiðir fengnir til að meta stautaundirbúning.

Efniviður og aðferðir. 67 pátttakendum var raðað i 3 hópa af handahófi. Í hópi 1 (T1), (n=22) var álklóríðkvoða notuð ein og sér. Í hópi 2 (T2), (n=23) var præði pakkað og álklóríð kvoða einnig notuð. Í samanburðarhópnum (C), (n=22) voru 2 præðir notaðir við tannholdsfærsluna.

Klínískar mælingar voru gerðar á tannholdi fyrir meðferð sem og 30ะ10 dögum eftir límingu tanngervisins. Study módel voru gerð á ákveðnum stigum meðferðar og staðlaðar ljósmyndir voru teknar af peim. Breytingar í hæð búkkal tannholdsbrúnar voru mældar af ljósmyndum í myndaforriti. Auk pess voru viðbrögð sjúklinga könnuð og mat lagt á stautaundirbúninginn með VAS-aðferðinni. Niðurstöður. Rannsóknartennur allra hópanna voru eins m.t.t. klínískra mælinga, utan pess að tennur sem höfðu fengið krónulengingu fyrir meðferð voru marktækt fleiri î T1 borið saman við hina hópana. Á tímabilinu frá máttöku að límingu varð aukning í hæð tannholdsbrúnar upp á 0.058 mm (SD 0.13) íT1 og 0.013 mm (SD 1.19) í T2. Hins vegar, fannst væg tannholdsrýrnun upp á 0.049 mm (SD 0.13) í C. Niðurstöður allra hópanna sýndi að í $21 \%$ tilfella jókst hæð tannholdsbrúnar um >0.1mm, 58\% tannanna höfðu stöðuga tannholdsbrún $(0 \pm 0.10 \mathrm{~mm}), 21 \%$ tilfella sýndi væga tannholdsrýrnun (0.1-0.5 mm) en ekkert tilfelli sýndi meðal-eða alvarlega rýrnun (>0.5 mm). Væg tannholdsrýrnun varð i 8\% tilfella í T1, 23\% íT2 og 32\% í C. Munurinn í tíðnidreifingunni milli hópanna var marktækur ( $p=.015)$.

15 pátttakendur (24\%) lýstu ópægindum eftir máttökuna. Munurinn milli hópanna var ómarktækur. Tannsmiðum fannst marktækt erfiðara að undirbúa stauta í T1 (VAS 79) og T2 (VAS 82), borið saman við C (VAS 93), ( $p=.003)$.

Ályktanir. Væg tannholdsrýrnun (<1 mm) er líklegri pegar præðir eru notaðir við tannholdsfærslu fyrir máttöku samanborið við álklóríðkvoðu. Hins vegar er líklegra að tannsmiðir eigi erfiðara með að greina krónubrúnir í mátum par sem álklóríðkvoða er notuð

Lykilorð: Álklóríðkvoða, máttaka, tannholdsfærsla, tannholdsrýrnun, præðir 


\section{Inngangur}

Tannstudd tanngervi eru algeng meðferð við uppbyggingar skemmdra tanna, tannleysi og til útlitsbætingar $(1,2)$. Rannsóknir benda til pess að tannskurðarbrúnir ofan tannholdsbrúnar séu vænstar tannholdinu (3-7). Hins vegar er oft pörf fyrir að staðsetja tannskurðarbrúnir undir tannholdsbrún, til dæmis til að auka hæð tannveggja en ekki síst vegna útlits. Í peim tilfellum er nauðsynlegt að færa tannholdsbrún tímabundið frá tannskurði til pess að bæta aðstæður fyrir máttöku svo hægt sé að smíða vel passandi tanngervi. Í stuttu máli er hægt að skipta aðferðunum við tannholdsfærslu i prennt: skurðaðferðir, mekanískar aðferðir og sambland peirra tveggja (8).

Thompson lýsti mekanískri aðferð árið 1951, pegar hann sagði fyrstur frá notkun práđa við tannholdsfærslu (9). Hann vætti pá eingöngu með vatni en ekki efnablöndu. Síðar, hefur tíðkast að væta præðina i efnablöndum af ýmsu tagi (10). Rannsóknir á slíkum aðferðum á tannholdsfærslu hafa gefið mismunandi niðurstöður. pær hafa ýmist lýst engri tannholdsrýrnun við meðferð $(11,12)$ en einnig lýst 0.2 mm tannholdsrýrnun sem afleiðingu af meðferð $(13,14)$. Efnablandin mekanísk aðferð við tannholdsfærslu hefur nú verið staðfest sem árangursrík (e. effective) og er jafnframt sú algengasta sem tannlæknar nota $(8,15,16)$.

Nýrri aðferðum við tannholdsfærslu hefur verið lýst, svo sem notkun álklóríð-kvoðu og sílikon-mátefna (8). pær aðferðir er hægt að nota einar og sér eða í bland við præði (17). Sýnt hefur verið fram á áreiðanleika og árangur pessara aðferða (17-20) en pær hafa ekki verið rannsakaðar með tilliti til hugsanlegrar tannholdsrýrnunar. Rannsóknir á áhrifum álklóríð-kvoðu á tannhold hafa verið misvísandi, ýmist sýnt fram á meiri bólgu samanborið við præði eða sílikonefni (21) eða sýnt engin slík áhrif (22). Hins vegar gætu slíkar práðlausar aðferðir verið pægilegri fyrir sjúklinga (19). Tilgangur pessarar slembnu, klínísku rannsóknar er að meta og bera samam prjár mismunandi aðferðir við tannholdsfærslu með pví að mæla, i fyrsta lagi tíðni og magn tannholdsrýrnunar, í öðru lagi upplifun sjúklings af pessum hluta meðferðarinnar og í priðja lagi mat tannsmiðs hversu auðvelt var að undirbúa stautinn fyrir tanngervasmíðina. Núlltilgátan er sú að pað er ekki marktækur munur milli hópanna hvað varðar tannholdsrýrnun, líðan sjúklinga eftir inngripið eða á mati tannsmiða.

\section{Efniviður og aðferðir}

Áður en gagnasöfnun hófst var rannsóknaráætlunin sampykkt af Vísindasiðanefnd (nr. 08-136) og tilkynning um rannsóknina var send til Persónuverndar. Pátttakendur undirrituðu upplýst sampykki fyrir páttöku.

67 manns í pörf fyrir fast tanngervi tóku pátt í rannsókninni. Rannsóknin fór fram við Tannlæknadeild Háskóla Íslands og á fjórum einkastofum í Reykjavík og nágrenni. Meðferðaraðilar voru almennir tannlæknar, sérfræðingar í tann-og munngervalækningum og tannlæknanemar undir leiðsögn kennara. Farið var ítarlega yfir aðferðir rannsóknarinnar áður en hún hófst til að samræma vinnubrögð milli meðferðaraðila (e. calibration). pátttakendur purftu að vera heilsuhraustir og í pörf fyrir fast tanngervi. Peir fengu tannhreinsun og leiðbeiningar um góðar munnhirðuvenjur. Ekki voru fleiri en tvær stoðtennur hjá hverjum pátttakanda notaðar í rannsókninni. Grunnupplýsingar um ástand stoðtanna voru skráđar fyrir meðferð. Hreyfanleiki var metinn samkvæmt Miller (23). Tannholdsrýrnun og pokadýpt voru mæld á sex stöðum við hverja tönn. Blæðing við pokamælingu var metin á fjórum stöđum við hverja tönn og skráð. pykkt tannholds var mæld og skráð, 2 mm fyrir ofan tannholdsbrún með tannholspjöl \#15. (VDW Sterile K-Files; VDW) Hæð keratínseraðs tannholds var mæld með pokamæli og skráð, námundað við næsta millimeter.

Pátttakendum var skipt upp í prjá hópa á slembinn máta, tvo tilraunahópa og einn viðmiðunarhóp. Pví var pannig háttað að lokuð, ógagnsæ umslög með hópavali voru opnuð af meðferðferðaraðila rétt áður en lokamáttaka fór fram. Pátttakendur fengu heim með sér verkjaeyðublað sama dag með peim leiðbeiningum að fylla út sama kvöld og skila í næstu heimsókn. Notast var við Visual Analogue Scale (VAS) aðferðina til eigin mats pátttakenda á ópægindum. Tannsmiðirnir sem fengu verkefnin mátu hversu auðvelt var að skera frá og undirbúa stautinn, en peir höfðu ekki vitneskju um hvaða aðferð var notuð við tannholdsfærsluna. Notast var við vAS aðferðina par sem 0 hafði pá pýðingu að „ómögulegt var að staðsetja tannskurðarbrúnina” en 100 að "enginn vafi var hvar tannskurðarbrún var staðsett". Fyrir tannholdsfærsluna og lokamáttökuna var alginat-mát (Jeltrate; Dentsply) tekið í stubbmátskeið sem áđur hafði verið pakin með alginat-lími (Fix Tray Adhesive Aerosol; Dentsply). Sérstök gát var höfð á að fylgja leiðbeiningum framleiðanda alginatsins hvað varðar hlutfall vatns og dufts. Steypt var strax í mátin með harðgifsi til að fá study módel \#1. 
22 pátttakendur röđuðust í hóp T1, par sem tannholdsfærsla var gerð með álklóríð-kvoðunni einni saman (Expasyl, Acteon). Kvoðunni var komið fyrir í tannholdssúlkus með par til gerðri sprautu, látin liggja par í 2 mínútur áður en skolað var rækilega með vatni og purrkað vel fyrir lokamáttökuna. 23 pátttakendur röðuðust í hóp T2, par sem tannholdsfærsla var gerð með grönnum præði (\#000, \#00, eða \#0) mesialt, lingualt og distalt eingöngu en álklóríðkvoðu var komið fyrir i súlkus umhverfis alla stoðtönnina par á eftir, látin verka i tvær mínútur áđur en skoluð vel í burtu og svæðið purrkað fyrir lokamáttökuna. 22 pátttakendur röðuðust í hóp C, samanburðarhópinn. Tveimur lögum af práðum var komið fyri i i súlkus umhverfis alla stoðtönnina, fyrst grönnum præði (\#000, \#00, eða \#0) og síðar sverari præði (\#1 eða \#2) yfir pann fyrri. Rétt fyrir lokamáttökuna var sá sverari fjarlægður. Í öllum hópum voru prjónaðir præðir úr bómull notaðir (Ultrapak; Ultradent Products, Inc.) præðirnir voru vættir í blæðingarhemjandi lausn fyrir notkun og var gerð hennar skráð fyrir hvert tilfelli i hópum T2 og C.

Tvær gerðir blæðingarhemjandi lausna voru notaðar í rannsókninni: 14\% bufferað álklóríð (Hemodent; Patterson Dental) og 20\% járnsúlfat (Visco Stat; Ultradent Products, Inc.). Mátefnin sem notuð voru í lokamáttökur voru ýmist polyether eða sílikon. Engin tímamörk voru sett á tannholdsfærsluna né hversu margar tilraunir purfti til að ná nægilega góðu máti en pað var klínískt mat meðferðaraðila í hvert skipti. Heildartíminn var pví ekki tekinn sérstaklega en fjöldi máta var skráður. Lögð var áhersla á að bráðabirgðakrónur væru vandaðar hvað varðar lögun og fall að brúnum. Pátttakendur fengu kennslu í að nota tannpráð og mjúkan tannbursta til að halda mjúkvef umhverfis stoðtennur heilbrigðum.

pegar krónuskil áttu sér stað, pá var tekið alginat stubbmát rétt fyrir límingu tanngervisins og study módel \#2 útbúið frá pví. Strax eftir límingu var annað slíkt alginat mát tekið og study módel \#3 útbúið í kjölfarið.

Fjórða skoðun fór fram $30 \pm 10$ dögum eftir límingu tanngervisins. Alginat mát var tekið og study módel \#4 útbúið. Einnig var tannholdsrýrnun, pokadýpt og blæðing við pokamælingu skráð í pessari sömu heimsókn.

Staðlaðir indexer voru gerðir úr sílikon mátefni (President Putty, Coltene/Whaledent) fyrir study módel \#1 og \#2 annars vegar og hins vegar fyrir study módel \#3 og \#4. Teknar voru staðlaðar ljósmyndir af öllum study módelunum fjórum. Notuð var Canon EOS 7D myndavél með stórlinsu og hringljósgjafa (F-stop: f/22, tökutími 1/250 sec., ISO-800, fócal length 100 mm) í 30 cm fjarlægð. Ljós- myndum var hlaðið upp í myndaforrit (Photoshop CS5 Extended; Adobe) og var tannholdsbrún staðsett og merkt í forritinu. Pví næst var stöðluð ljósmynd af study módeli \#1 færð yfir staðlaða ljósmynd af study módeli \#2 pannig að báđar myndir sáust, samkvæmt fyrirfram skilgreindum föstum punktum á aðliggjandi tönnum. Munurinn á milli staðsetningar tannholdsbrúnar fyrir og eftir máttöku var mæld í forritinu í millimetrum talið. pað sama var gert með stöðluðu ljósmyndirnar af study módelum \#3 og \#4. Til pess að sannreyna áreiðanleika aðferðarinnar, pá voru 17 tilfelli valin af handahófi, eða 25\% tilfellanna, sem mælingarnar voru endurteknar á og mælivillan metin tölfræðilega.

Tölfræði. Lýsandi tölfræði á grunnupplýsingum pátttakenda og stoðtanna var reiknuð, p.m.t. meðaltöl, staðalfrávik, 95\% vikmörk og prósentudreifing flokkabreyta. Einhliða dreifigreining var notuð til að bera saman breytur innan hópanna: a) staðsetningu tannholdsbrúnar (mm), b) meðal-pokadýpt $(\mathrm{mm}), \mathrm{c})$ tannholdspykkt, d) hæð keratínseraðs tannholds ( $\mathrm{mm}$ ) og e) meðaltalsbreytingar í hæð tannholdsbrúnar (mm).

Ópöruð t-próf voru einnig notuð til að bera saman meðaltalsgildi milli hópanna. Til að bera saman ólíka hópa var kí-kvaðrat próf notað og p-gildi reiknuð. Tíðnidreifing var einnig notuð til að lýsa frekari breytingum í hæð tannholdsbrúnar og aðhvarfsgreining gerð til að bera saman tíðnidreifinguna milli hópanna. Fyrir suma pátttakendur voru tvær stoðtennur notaðar í rannsókninni. Par af leiðandi var ekki hægt að líta á sem svo að útkomur væru óháðar og pví leiðrétt fyrir pví. Til að áætla mælivillu aðferðarinnar voru 25\% tilfellanna notuð til að mæla meðaltalsbreytingu, 95\% vikmörk og spönn. Parað t-próf, Spearman stuðull og Bland Altman rit voru notuð til að bera saman mælingar og fá fram mælivillu. Útkomur úr VAS voru kynntar sem meðaltöl, staðalfrávik, miðgildi og dreifing. Í peim tilgangi að bera saman hópa voru skor milli 91 og 100 flokkuð sem jákvæð en skor upp á 90 og undir voru flokkuð sem neikvæð. Öll tölfræði var gerð í Stata version 12.2 (Stata Corporation).

\section{Niðurstöður}

Rannsóknin fór fram yfir tveggja ára tímabil. Pátttakendur voru 67 talsins, meðalaldur var 49.8 ár (SF 12.5, spönn 20-80) á peim tímapunkti sem lokamáttaka fór fram. Fimm pátttakendur mættu ekki í heimsókn númer 4, prátt fyrir ítrekaðar tilraunir til að ná í pá. Samtals voru 92 stoðtennur metnar í rannsókninni, par sem 25 pátttakendur höfðu tvær stoðtennur og eina stoðtönn höfðu peir 42 pátttakendur sem eftir eru. Lýsandi tölfræði hópanna er að finna í töflu 1. 
Tafla 1. Grunnupplýsingar pátttakenda

\begin{tabular}{|c|c|c|c|c|c|}
\hline & Allir & $\mathrm{T1}$ & T2 & C & p-gildi \\
\hline Fjöldi & 67 & 22 & 23 & 22 & n.a. \\
\hline Aldur (meðaltal, SD) & $49.8 \pm 12.5$ & $48.7 \pm 13.8$ & $48.8 \pm 10.6$ & $52.0 \pm 13.3$ & n.a. \\
\hline Fjöldi tanna & 92 & 28 & 35 & 29 & n.a. \\
\hline Hreyfanleiki (Miller Index) (\%) & $10 \%$ & $8 \%$ & $15 \%$ & $7 \%$ & $.608^{*}$ \\
\hline Rótfylltar (\%) & $44 \%$ & $35 \%$ & $54 \%$ & $41 \%$ & $.500^{*}$ \\
\hline Krýndar (\%) & $25 \%$ & $4 \%$ & $33 \%$ & $34 \%$ & $.052^{*}$ \\
\hline Stiftisuppbygging (\%) & $24 \%$ & $15 \%$ & $34 \%$ & $21 \%$ & $.343^{*}$ \\
\hline Krónulenging (\%) & $3.3 \%$ & 3 & 0 & 0 & $<.001^{*}$ \\
\hline Pokadýpt (mm) (meðaltal, 95\% C.I.) & $\begin{array}{c}2.3 \\
(2.2-2.4)\end{array}$ & $\begin{array}{c}2.2 \\
(2.1-2.4)\end{array}$ & $\begin{array}{c}2.4 \\
(2.1-2.6)\end{array}$ & $\begin{array}{c}2.4 \\
(2.1-2.6)\end{array}$ & $.658^{* *}$ \\
\hline $\begin{array}{l}\text { Tannholdspykkt (mm) (meðaltal, 95\% } \\
\text { C.I.) }\end{array}$ & $\begin{array}{c}1.4 \\
(1.3-1.6)\end{array}$ & $\begin{array}{c}1.4 \\
(1.1-1.7)\end{array}$ & $\begin{array}{c}1.5 \\
(1.3-1.7)\end{array}$ & $\begin{array}{c}1.3 \\
(1.0-1.6)\end{array}$ & $.702^{* *}$ \\
\hline $\begin{array}{l}\text { Hæð kerat tannholds (mm) (meðaltal, } \\
95 \% \text { C.I.) }\end{array}$ & $\begin{array}{c}3.9 \\
(3.6-4.3)\end{array}$ & $\begin{array}{c}3.7 \\
(3.2-4.3)\end{array}$ & $\begin{array}{c}4.2 \\
(3.5-4.9)\end{array}$ & $\begin{array}{c}3.7 \\
(3.2-4.3)\end{array}$ & $.680^{\star *}$ \\
\hline Blæðing við pokamælingu (\%) & $21 \%$ & $20 \%$ & $21 \%$ & $22 \%$ & $.931^{* * *}$ \\
\hline
\end{tabular}

*Ki-kvaðrat próf

**Einhliða dreifigreining

***Meðaltalsgreining

Ekki var marktækur munur á hópunum hvað varðar grunnmælingar, að pví undanskildu að allar prjár tennurnar sem gerðar voru krónulengingar við lentu í hóp T1. Hins vegar liðu a.m.k. 12 vikur frá krónulengingaraðgerð og að lokamáttöku pannig að mjúkvefsgræðslu var að fullu lokið. Meðalfjöldi máta í T1 var 1.4 (95\% vikmörk 1.2 1.7, spönn 1-3), 1.3 í T2 (95\% vikmörk 1.1 - 1.5, spönn 1-3) og 1.1 í C (95\% vikmörk 1.0 - 1.3, spönn 1-2). í hópi T1 var fyrsta mát talið nægilega gott i $61 \%$ tilfella. Í hópum T2 og C voru pessar tölur 76\% og 86\%. Ekki var marktækur munur milli hópanna $(\mathrm{p}=0.216)$. Hjá tveimur pátttakendum í hópi T1 gekk ekki að taka nægilega gott lokamát af krónubrúnum vegna ónægrar færslu tannholds.

Breytingar á tannholdshæð, samkvæmt meðtaltölum og tíðnidreifingu, frá pví fyrir tannskurð og að lokamáttöku, má sjá í töflu 2. Tíðnidreifingin var skilgreind á pennan hátt: aukning í hæð tannholdsbrúnar (>0.1 mm), stöðug tannholdsbrún ( $0 \pm 0.1 \mathrm{~mm})$, lítil tannholdsrýrnun (0.1-0.5 $\mathrm{mm})$, meðal tannholdsrýrnun (0.5-1.0 mm), og alvarleg tannholdsrýrnun (>1.0 mm). Tíđni lítillar tannholdsrýrnunar var 8\% í T1, 23\% í T2 and 32\% í C. Hvað varðar meðal tannholdsrýrnun pá var munurinn milli hópanna marktækur $(p=0.015)$. Pegar munur einstakra hópa voru kannaður, kom í ljós að einungis var munurinn milli T1 og C marktækur $(p=0.004)$.
Staðsetning tannholdsbrúnar var einnig metin á tímabilinu frá pví tanngervi var límt varanlega og par til u.p.b. einum mánuði síðar, með pví að bera saman myndir af study módelum \#3 og \#4. Niðurstöður pess eru teknar saman í töflu 3. Munurinn sem fannst á tíðnidreifingunni var marktækur $(p<0.001)$.

Að lokum, voru breytingar á hæð tannholdsbrúnar metnar fyrir allt tímabilið með pví að taka saman mælingar frá áðurnefndum ljósmyndum. (Tafla 4) Marktækur munur fannst á bæði meðaltalsbreytingum í staðsetningu tannholdsbrúnar og einnig í tíðnidreifingu ( $p=0.009$ og 0.036). Frekari könnun sýndi að aðeins var marktækur munur milli $\mathrm{T1}$ og $\mathrm{C}(\mathrm{p}=0.002)$. Ekki var marktækur munur í tannholdsrýrnun milli peirra sem höfðu pykkt (>1.5 mm) og punnt $(<1.5 \mathrm{~mm}$ ) tannhold pegar litið var yfir allt tímabilið ( $p<0.72$ ). Einnig kom í ljós að pátttakendur sem höfðu lága hæð kartínseraðs tannholds (<3 mm) voru ekki í aukinni hættu á tannholdsrýrnun borið saman við pá sem höfðu meiri tannholdshæð $(p<0.86)$.

Klínískar mælingar voru endurteknar í fjórðu heimsókn. Krónubrún var að meðaltali staðsett $0.3 \mathrm{~mm}$ neðan tannholdsbrúnar (e. subgingivalt) við allar stoðtennurnar (SD 0.73). Við frekari könnun kom í ljós að krónubrún var staðsett dýpra undir tannholdi í hópi T1 borið saman við hina hópana ( $p=0.034)$. 
Tafla 2. Hæðarbreytingar tannholdsbrúnar fyrir og 2v eftir máttöku (\#1 vs. \#2)

\begin{tabular}{|c|c|c|c|c|c|}
\hline & Allir $(n=90)$ & $\mathrm{T} 1(\mathrm{n}=26)$ & $\mathrm{T} 2(\mathrm{n}=35)$ & $C(n=29)$ & p-gildi \\
\hline $\begin{array}{l}\text { Hæðarbreytingar tannholdsbrúnar } \\
(\mathrm{mm}) \text { (meðaltal, 95\% C.I.)* }\end{array}$ & $\begin{array}{c}0.006 \\
(-0.025-0.036)\end{array}$ & $\begin{array}{c}0.058 \\
(0.006-0.110)\end{array}$ & $\begin{array}{c}0.013 \\
(-0.041-0.067)\end{array}$ & $\begin{array}{c}-0.049 \\
(-0.098-0.001)\end{array}$ & $.015^{*}$ \\
\hline Hæðaraukning >0.1mm & $21 \%$ & $35 \%$ & $23 \%$ & $7 \%$ & \multirow{5}{*}{$.096^{* *}$} \\
\hline Stöðug tannholdsbrún $0 \pm 0.1 \mathrm{~mm}$ & $58 \%$ & $58 \%$ & $54 \%$ & $62 \%$ & \\
\hline Lítil tannholdsrýrnun 0.1-0.5mm & $21 \%$ & $7 \%$ & $23 \%$ & $31 \%$ & \\
\hline Meðal tannholdsrýrnun 0.5-1.0 mm & $0 \%$ & $0 \%$ & $0 \%$ & $0 \%$ & \\
\hline Alvarleg tannholdsrýrnun >1.0 mm & $0 \%$ & $0 \%$ & $0 \%$ & $0 \%$ & \\
\hline
\end{tabular}

*Einhliða dreifigreining

**Ki-kvaðrat próf

Tafla 3. Hæðarbreytingar tannholdsbrúnar frá ísetningu að $30 \pm 10$ dögum seinna (\#3 vs. \#4)

\begin{tabular}{|c|c|c|c|c|c|}
\hline & Allir $(n=80)$ & $T 1(n=23)$ & $T 2(n=30)$ & $C(n=27)$ & p-gildi \\
\hline $\begin{array}{l}\text { Hæðarbreytingar tannholdsbrúnar } \\
\text { (mm) (meðaltal, 95\% C.I.) }\end{array}$ & $\begin{array}{c}-0.021 \\
(-0.056-0.013)\end{array}$ & $\begin{array}{c}0.034 \\
(-0.030-0.098)\end{array}$ & $\begin{array}{c}-0.043 \\
(-0.115-0.029)\end{array}$ & $\begin{array}{c}-0.044 \\
(-0.080-0.009)\end{array}$ & $.163^{*}$ \\
\hline Hæðaraukning >0.1mm & $19 \%$ & $30 \%$ & $27 \%$ & $0 \%$ & \multirow{5}{*}{$<.001$ ** } \\
\hline Stöðug tannholdsbrún $0 \pm 0.1$ mm & $51 \%$ & $48 \%$ & $33 \%$ & $74 \%$ & \\
\hline Lítil tannholdsrýrnun 0.1-0.5 mm & $29 \%$ & $22 \%$ & $37 \%$ & $26 \%$ & \\
\hline Meðal tannholdsrýrnun 0.5-1.0 mm & $1 \%$ & $0 \%$ & $3 \%$ & $0 \%$ & \\
\hline Alvarleg tannholdsrýrnun >1.0 mm & $0 \%$ & $0 \%$ & $0 \%$ & $0 \%$ & \\
\hline
\end{tabular}

*Einhliða dreifigriening

**Ki-kvaðrat próf

\section{Tafla 4. Hæðarbreytingar tannholdsbrúnar frá upphafi meðferðar par til $30 \pm 10$ days eftir ísetningu (\#1 vs. \#4)}

\begin{tabular}{|c|c|c|c|c|c|}
\hline & Allir $(n=80)$ & $T 1(n=23)$ & $T 2(n=30)$ & $C(n=27)$ & p-gildi \\
\hline $\begin{array}{l}\text { Hæðarbreytingar tannholdsbrúnar } \\
(\mathrm{mm}) \text { (meðaltal, 95\% C.I.) }\end{array}$ & $\begin{array}{c}-0.001 \\
(-0.054-0.051)\end{array}$ & $\begin{array}{c}0.111 \\
(0.030-0.193)\end{array}$ & $\begin{array}{c}-0.011 \\
(-0.113-0.092)\end{array}$ & $\begin{array}{c}-0.087 \\
(-0.160--0.014)\end{array}$ & $.009^{*}$ \\
\hline Hæðaraukning >0.1mm & $35 \%$ & $61 \%$ & $33 \%$ & $15 \%$ & \multirow{5}{*}{$.036^{* *}$} \\
\hline Stöðug tannholdsbrún $0 \pm 0.1 \mathrm{~mm}$ & $40 \%$ & $22 \%$ & $47 \%$ & $48 \%$ & \\
\hline Lítil tannholdsrýrnun 0.1-0.5mm & $20 \%$ & $17 \%$ & $13 \%$ & $30 \%$ & \\
\hline Meðal tannholdsrýrnun 0.5-1.0mm & $5 \%$ & $0 \%$ & $7 \%$ & $7 \%$ & \\
\hline Alvarleg tannholdsrýrnun >1.0 mm & $0 \%$ & $0 \%$ & $0 \%$ & $0 \%$ & \\
\hline
\end{tabular}

*Einhliða dreifigreining

**Ki-kvaðrat próf 


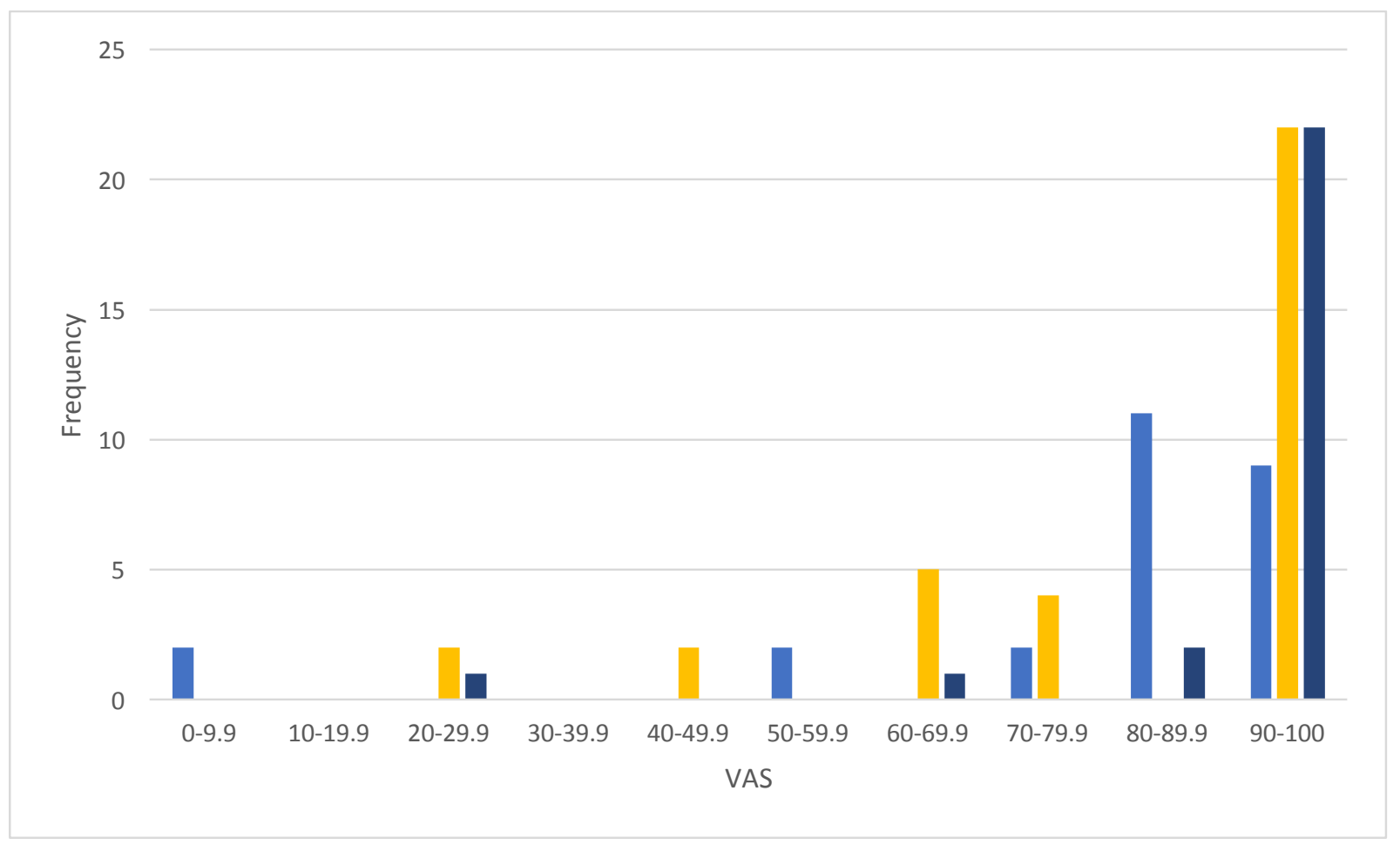

Mynd 1. VAS skor tannsmiða, hversu auðveldur var stauta-undirbúningur

prír pátttakendur skiluðu ekki inn verkjaspurningablaði. 15 pátttakendur (24\%) sögðust hafa haft ópægindi eftir máttökuna. Meðaltalsskor á VAS var 27 (SD 20). Pessir 15 pátttakendur höfðu samtals 21 rannsóknatönn en 10 peirra voru rótfylltar en 11 voru lifandi tennur. Séu hóparnir skoðaðir m.t.t. verkja, pá voru 20\% peirra î T1, 24\% í T2 og 29\% í C. Pessi munur er ómarktækur.

Tannsmiðir mátu hversu auðvelt var að greina tannskurðarbrún við stauta-undirbúning. Niðurstöður pess er að finna á mynd 1. Sé pað skoðað fyrir hópana var meðal-VAS skor í T1 upp á 79. Pau 2 tilfelli sem ekki var að hægt að ná nægilega góðu lokamáti i T1 fengu VAS skor upp á 0 . Fyrir T2 hóp var VAS skorið 82 (SD 22) og C hóp 93 (SD 15). Samkvæmt tíðnidreifingu pá var álit tannsmiðsins pannig að honum fannst auðvelt að undirbúa stautinn í 35\% tilfella íT1, 51\% î T2 og 81\% í C og var pessi munur marktækur ( $p=0.003)$. Pessar tölur voru miðaðar við VAS upp á 91-100.

\section{Umræða}

Ekki hefur áður verið fjallað um áhrif álklóríð-kvoðu á tannholdsrýrnun, svo höfundar viti, og aðeins örfáar klínískar rannsóknir hafa metið staðsetningu tannholdsbrúnar fyrir og eftir máttökur. Tannholdsrýrnun hefur verið mæld eftir notkun bómullarpráđa og hefur 0.2-0.26 mm rýrnun komið í ljós, að meðaltali $(13,14)$. pað er sambærilegt við pá tannholdsrýrnun sem mæld er í pessari rannsókn í samanburðarhópnum C. Niðurstöður pessarar rannsóknar er að lítil tannholdsrýrnun er líklegri pegar bómullarpræðir eru notaðir, borið saman við álklóríð-kvoðu. Sjúklingaháðir pættir, t.d. tannholdspykkt og hæð kertinseraðs tannholds skipti ekki máli í pví samhengi.

Tannsmiðir áttu auðveldara með að undirbúa stautinn í peim hópi sem præðir voru notaðir, borið saman við álklóríðkvoðu. Par að auki gekk lokamáttakan ekki upp í tveimur tilfellum í hópi T1 vegna pess að tannskurðarbrúnin var ekki nægilega heilleg í mátunum premur sem tekin voru. Í báðum tilfellum var um að ræða fyrsta jaxl í neðri gómi.

Fáar greinar eru til sem skoða gæði máta sem tekin eru með hjálp kvoðu eingöngu. Tannholdsfærsla með práðum hefur verið tengd góðum mátum og betri gæðum samanborið við aðrar práđlausar tannholdsfærslur $(24,25)$. par að auki hefur verið sýnt fram á að erfitt geti verið að ná nákvæmu máti sé vídd súlkus undir 0.2 mm (26). Ónæg útvíkkun tannholds (e. lateral expansion) gæti hugsanlega verið vandamál pegar kvoða er notuð ein og sér. petta atriði gæti útskýrt erfiðleikana sem komu upp við máttökur í hópi T1 en einnig pá staðreynd að tannsmiðum fannst auðveldara að undirbúa stauta i C-hóp. 
Niðurstöður pessar eru mikilvægar upplýsingar fyrir tannlækna sem vinna tanngervasmíði á eigin tennur. Gert er ráð fyrir að vilji sé til að lágmarka hættuna á tannholdsrýrnun, sérstaklega á útlitslega mikilvægu svæði. Pess vegna mætti færa rök fyrir pví að velja frekar kvoðuna heldur en præði í peim tilvikum. Hins vegar ættu tannlæknar að hafa í huga að tannskurðarbrúnir í mátinu verði hugsanlega ekki eins skýrar í peim aðstæðum og erfiðleikar gætu skapast á tannsmíðaverkstæðinu við smíði tanngervisins, sé kvoðan notuð ein og sér.

Við greiningu á breytingum á staðsetningu tannholdsbrúnar yfir allt rannsóknartímabilið pá jókst hæð tannholdsbrúnar í 35\% tilfella, 40\% tilfelli sýndu stöðuga tannholdsbrún, 20\% litla tannholdsrýrnun og 5\% tannholdsrýrnun í meðallagi. Alvarleg tannholdsrýrnun upp á $1.0 \mathrm{~mm}$ eða meira var ekki greind í pessari rannsókn. Af pessum tölum má greina að í 1/3 tilfellanna var tannholdsbrún staðsett ofar (meira coronalt) en fyrir tanngervasmíðina. Í samanburði hópanna, pá var petta mest áberandi í hópi T1. Mögulegar ástæður fyrir pessu gætu verið pær að aðgerðin sjálf í heildina, p.m.t. tannskurður undir tannholdi, tannholdsfærslan, máttakan og bráðabirgðakrónan olli ertingu á tannholdinu og par með aukinni hæð tannholdsbrúnar vegna tannholdsbólgu. Mjúkvefserting gæti einnig stafað beint af álklóríð-kvoðunni sem gæti skýrt muninn milli T1 og C. Pessi fullyrðing er í samræmi við aðra klíníska rannsókn um áhrif kvoðu á mjúkvef (21). Önnur möguleg ástæða fyrir pessu er tannholdsbólga í kjölfar ísetningar tanngervis með brúnir undir tannholdi (subgingival) en um slíkt hefur verið rætt áđur (27). Hins vegar eru pessar niðurstöður í samræmi við klínískar mælingar á krónubrúnum í hópi T1, en pær voru, að meðaltali, staðsettar lengra undir tannholdsbrún (e. subgingivalt) heldur en í öðrum hópum ( $p=0.034$ ). pannig styðja pessar niðurstöður enn frekar við pá tilgátu að minni tannholdsrýrnun er að finna í kjölfar notkunar kvoðu samanborið við præði.

í pessari rannsókn var bví lýst í nokkrum tilfellum að smáar misfellur í gifsi væru til staðar á tannskurðarbrúnum í hópum T1 og T2. Ekki eru til margar rannsóknir sem hafa skoðað milliverkun efna sem notuð eru við tannholdsfærslu og mátefna-hörðnunar. Hins vegar hefur ein rannsókn sýnt að hörðnun polyether mátefnis getur tekið lengri tíma en ella, í snertingu við álklóríð (28). Önnur rannsókn sýnir að nákvæmni sílikon mátefnis er ekki í hættu í nánd við álklóríð eða járnsúlfat en eins og í pessari rannsókn, sýndi hún smáar misfellur í yfirborði gifs (29).
Pessi rannsókn er slembin, klínísk samanburðarrannsókn með ágætum fjölda pátttakenda. Hún er að miklu leyti framkvæmd á stofu og er pess vegna líkleg til að gefa innsýn í heim hinnar almennu einkatannlæknastofu. Prátt fyrir pennan fjölda, yfir 20 manns í hverjum hóp með a.m.k. 28 stoðtennur, og pótt sums staðar hafi fundist marktækur munur milli breyta, pá má deila um hvort úrtakið hafi verið nægilega stórt til pess að greina með sönnu mun sem gæti skipt máli í klínískum praksís, p.e. útiloka týpu II villu.

Takmarkanir eru óumflýjanlegir fylgifiskar rannsókna sem nauðsynlegt er að minnast á. Stöðlun bráđabirgðakróna er erfið og er hugsanlegt að misfellur á brúnum og galli í formi hafi haft áhrif á tannholdið og valdið bólgu. (30) Rannsóknaraðilar höfðu mismunandi klíníska reynslu og gæti slíkt haft áhrif á niðurstöður. Skortur á starfsreynslu gæti valdið pví að máttöku pyrfti að endurtaka en meðalfjöldi máttaka upp á 1.1-1.4 verður að teljast innan eðlilegra marka. pað var ekki talið fýsilegt að staðla ýmsa hluti í rannsókninni par sem hún fór fram bæði í háskóla og á einkastofum, p.m.t. tímalengd práða í súlkus, blóðstöðvandi efni og mátefni. Pessi atriði eru ekki talin skipta máli par sem allir fylgdu sömu aðferðum en pó er ekki hægt að útiloka áhrif peirra á niðurstöður. Slembin niðurröðun í hópana ætti hins vegar að lágmarka áhrif slíkra pátta.

\section{Samantekt}

Pessi rannsókn bar saman notkun tvöfalds lags práða og álklóriðð-kvoðu við tannholdsfærslu fyrir máttöku. Hún sýndi að væg tannholdsrýrnun eru líklegri við notkun práða. Hins vegar, pótti tannsmiðum marktækt auðveldara að undirbúa staut undir tanngervið pegar præðirnir höfðu verið notaðir. Blanda af práðum og kvoðu gáfu ekki betri niðurstöður varðandi tannholdsrýrnun né undirbúning stauts. Ein aðferð vakti ekki meiri ópægindi en önnur hjá pátttakendum rannsóknarinnar.

\section{pakkir}

Sérstakar pakkir fá Gunnar Leifsson, Gunnlaugur Pór Guðmundsson, Jón Ólafur Sigurjónsson og Kjartan Pór Ragnarsson sem gáfu vinnu sína til aðstoðar við gagnaöflun. Rannsóknin var hluti af meistaranámi höfundar við Háskóla Íslands. Sérstakar pakkir fá Ellen Flosadóttir og Svend Richter fyrir ómetanlegan stuðning í náminu sem og prófdómurum Magnúsi Björnssyni og Guðjóni Axelssyni. Rannsóknin var styrkt af Vísindasjóði TFÍ og fyrirtækið Acteon lét af hendi Expasyl til notkunar í rannsókninni. 
Grein pessi er byggð á grein höfunda A multicenter randomized, controlled clinical trial comparing the use of displacement cords, an aluminum chloride paste, and a combination of paste and cords for tissue displacement sem birtist í J Prosthet Dent. 2018 ;119(1):82-88.

\section{Heimildir}

1. Pjetursson BE, Sailer I, Makarov NA, Zwahlen M, Thoma DS. All-ceramic or metalceramic tooth-supported fixed dental prostheses (FDPs)? A systematic review of the survival and complication rates. Part II: Multiple-unit FDPs. Dent Mater 2015;31:62439.

2. Sailer I, Makarov NA, Thoma DS, Zwahlen M, Pjetursson BE. All-ceramic or metalceramic tooth-supported fixed dental prostheses (FDPs)? A systematic review of the survival and complication rates. Part I: Single crowns (SCs). Dent Mater 2015;31:60323.

3. Valderhaug J. Periodontal conditions and carious lesions following the insertion of fixed prostheses: a 10-year follow-up study. Int Dent J 1980;30:296-304.

4. Loe H. Reactions to marginal periodontal tissues to restorative procedures. Int Dent J 1968;18:759-78.

5. Silness J. Periodontal conditions in patients treated with dental bridges. J Periodontal Res 1974;9:50-5.

6. Waerhaug J. Tissue reactions around artificial crowns. J Periodontol 1953;24:172-85.

7. Waerhaug J. Histologic considerations which govern where the margins of restorations should be located in relation to the gingiva. Dent Clin North Am 1960;4:161-76

8. Ahmed SN, Donovan TE. Gingival displacement: Survey results of dentists' practice procedures. J Prosthet Dent 2015;114:81-5.e1-2.

9. Thompson MJ. Exposing the cavity margin for hydrocolloid impressions. J South Calif Dent Assoc 1951;19:17-24.

10. Woycheshin FF. An evaluation of the drugs used for gingival retraction. J Prosthet Dent 1964;14:769-76.

11. Stark MM, Nicholson DJ, Soelberg KB, Kempler D, Pelzner RB. The effects of retraction cords and electrosurgery upon blood pressure and tissue regeneration in rhesus monkeys. J Dent Res 1977;56:881-8.

12. Azzi R, Tsao TF, Carranza FA, Jr., Kenney EB. Comparative study of gingival retraction methods. J Prosthet Dent 1983;50:561-5.

13. Ruel J, Schuessler PJ, Malament K, Mori D. Effect of retraction procedures on the periodontium in humans. J Prosthet Dent 1980;44:508-15.

14. Stuffken M, Vahidi F. Preimpression troughing with the diode laser: A preliminary study. J Prosthet Dent 2016;115:441-6.

15. Kumbuloglu O, User A, Toksavul S, Boyacioglu $\mathrm{H}$. Clinical evaluation of different gingival retraction cords. Quintessence Int 2007;38:e92-8.

16. Tabassum S, Adnan S, Khan FR. Gingival retraction methods: A systematic review. J Prosthod 2016.

17. Acar O, Erkut S, Ozcelik TB, Ozdemir E, Akcil M. A clinical comparison of cordless and conventional displacement systems regarding clinical performance and impression quality. J Prosthet Dent 2014;111:388-94.

18. Sarmento HR, Leite FR, Dantas RV, Ogliari FA, Demarco FF, Faot F. A double-blind randomised clinical trial of two techniques for gingival displacement. J Oral Rehab 2014;41:306-

19. Huang C, Somar M, Li K, Mohadeb JV. Efficiency of Cordless Versus Cord Techniques of Gingival Retraction: A Systematic Review. J Prosthodont 2015.

20. Bennani V, Aarts JM, Schumayer D. Correlation of pressure and displacement during gingival displacement: An in vitro study. J Prosthetic Dent 2016;115(3):296-300.

21. Al Hamad KQ, Azar WZ, Alwaeli HA, Said KN. A clinical study on the effects of cordless and conventional retraction techniques on the gingival and periodontal health. J Clin Periodontol 2008;35:1053-8.

22. Chandra S, Singh A, Gupta KK, Chandra C, Arora V. Effect of gingival displacement cord and cordless systems on the closure, displacement, and inflammation of the gingival crevice. J Prosthet Dent 2016;2:177-82.

23. Miller S. Textbook of periodontia. 3rd ed. Philadelphia: Blakiston Company; 1950.
24. Beier US, Kranewitter R, Dumfahrt H. Quality of impressions after use of the Magic FoamCord gingival retraction system--a clinical study of 269 abutment teeth. Int J Prosthodont 2009;22:143-7.

25. Wostmann B, Rehmann P, Trost D, Balkenhol M. Effect of different retraction and impression techniques on the marginal fit of crowns. J Dent 2008;36:508-12.

26. Laufer BZ, Baharav H, Cardash HS. The linear accuracy of impressions and stone dies as affected by the thickness of the impression margin. Int J Prosthodont 1994;7:247-52.

27. Valderhaug J, Birkeland JM. Periodontal conditions in patients 5 years following insertion of fixed prostheses. Pocket depth and loss of attachment. J Oral Rehab 1976;3:237-43.

28. Nowakowska D, Raszewski Z, Zietek M, Saczko J, Kulbacka J, Wieckiewicz W. The setting time of polyether impression materials after contact with conventional and experimental gingival margin displacement agents. J Prosthodont 2016.

29. O'Mahony A, Spencer P, Williams K, Corcoran J. Effect of 3 medicaments on the dimensional accuracy and surface detail reproduction of polyvinyl siloxane impressions. Quintessence Int 2000;31:201-6.

30. Donaldson $\mathrm{D}$. The etiology of gingival recession associated with temporary crowns. J Periodontol 1974:45:468-71. 
English Summary

\section{A multicenter randomized, controlled clinical trial comparing the use of displacement cords, an aluminum chloride paste, and a combination of paste and cords for tissue displacement}

ERNA R. EINARSDOTTIR, DDS, MS, ASSISTANT PROFESSOR, PROSTHODONTICS, FACULTY OF ODONTOLOGY, UNIVERSITY OF ICELAND,

NIKLAUS P. LANG, DR MED DENT, MS, PHD, PROFESSOR EMERITUS, UNIVERSITY OF BERNE AND UNIVERSITY OF ZURICH, SWITZERLAND

THOR ASPELUND, MS, PHD PROFESSOR, CENTER OF PUBLIC HEALTH SCIENCES, FAC. OF MEDICINE, UNIVERSITY OF ICELAND

BJARNI E. PJETURSSON, DR MED DENT, PHD PROFESSOR AND HEAD OF RESTORATIVE DENTISTRY, FACULTY OF ODONTOLOGY, UNIVERSITY OF ICELAND

ICELANDIC DENTAL JOURNAL 2019; 37: 52-60

doi: 10.33112/tann.37.1.6

Statement of problem. Gingival recession due to soft tissue displacement for impression-making in fixed prosthodontics may pose a problem for treatment success in the esthetic areas of the mouth. There is limited knowledge about the soft tissue reaction of common gingival displacement methods.

Purpose. The purpose of this randomized controlled clinical trial (RCT) was to evaluate changes in the marginal soft tissue height to 3 different gingival tissue displacement techniques during fixed prosthodontics definitive impressions of natural teeth. Additionally, participants' perception of the intervention and technicians' evaluation of the easiness of die preparation was evaluated using Visual Analogue Scales.

Material and Methods. Sixty-seven individuals were randomized into 3 groups. In test group 1 ( $T 1)$, $(n=22)$ only aluminum chloride paste was used to retract the gingiva. In Test group 2 (T2), ( $n=23)$ a cord was inserted and aluminum chloride paste was used as well. In the Control group (C), $(n=22) 2$ cords were used to retract the gingiva (double cord technique). Clinical measurements of the gingival position were made before treatment initiation and $30 \pm 10$ days after prosthesis delivery. Study casts were fabricated at different stages of the treatment, standardized photographs of these were taken and changes in the buccal gingival position measured using a graphics editing software. In addition, participants' perception of the clinical procedure and technicians' evaluation of the die preparation were recorded.

Results. Baseline clinical parameters of the study teeth were the same for all groups except for surgical crown lengthening, for which all 3 included cases were allocated to T1. In the period between impression and delivery, a minor gain in gingival height was reported of $0.058 \mathrm{~mm}$ (SD 0.13) for T1 and $0.013 \mathrm{~mm}$ (SD 1.19) for T2. However, a minor gingival recession of $0.049 \mathrm{~mm}$ (SD 0.13 ) was reported for group C. The results for all groups showed that $21 \%$ of abutment teeth gained $>0.1 \mathrm{~mm}$ gingival height, $58 \%$ had stable gingival height $(0 \pm 0.10 \mathrm{~mm}), 21 \%$ showed minor gingival recessions $(0.1-0.5$ $\mathrm{mm}$ ), and no abutment teeth showed moderate or severe gingival recessions ( $>0.5 \mathrm{~mm}$ ). The incidence of minor gingival recession was $8 \%$ in $\mathrm{T} 1,23 \%$ in $\mathrm{T} 2$ and $32 \%$ in $\mathrm{C}$. The difference in frequency distribution of the gingival position between the 3 groups reached statistical significance $(p=.015)$.

Fifteen participants, (24\%) experienced some discomfort after the procedure. The difference between the groups was not significant. The dental technicians found the working die preparation significantly more challenging for group T1 (VAS 79) and T2 (VAS 82), as compared to group C (mean VAS 93), ( $p=.003)$.

Conclusion. Minor or moderate gingival recession $(<1 \mathrm{~mm})$ is more likely to occur when conventional cords are used during impression making. However, utilizing the double cord technique, the dental technicians found die preparation significantly less challenging compared with impressions made using the aluminum chloride paste.

Keywords: Aluminum chloride paste, impression, gingival displacement, gingival recession, retraction cords Correspondence: Erna Rún Einarsdóttir, e-mail: ere@hi.is 